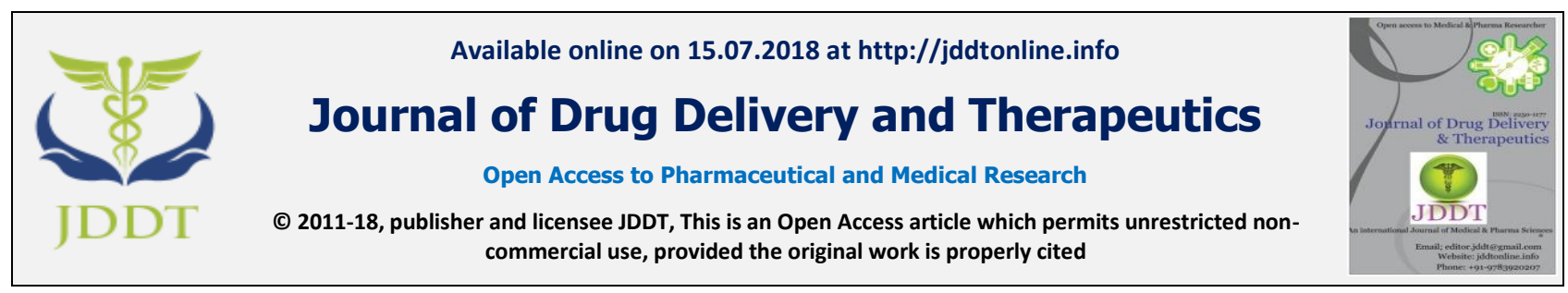

Open $\odot$ Access

Research Article

\title{
PHARMACOLOGICAL EVALUATION OF SOLANUM VIARUM DUNAL LEAVES EXTRACT FOR ANALGESIC AND ANTIPYRETIC ACTIVITIES
}

\author{
Meena Kausar,* B. K. Singh \\ Department of Pharmaceutical Sciences, Bhimtal, Kumaun University, Nainital-263136, India
}

\section{ABSTRACT}

The family Solanaceae consists of many plants, one of them is Solanum viarum Dunal. This plant contains chemical constituents like Solasodine which is found in many plants of Solanaceae family. The Solasodine have many medicinal properties and used as cardiotonic, antifungal, antispermatogenic, antiandrogenic, immunomodulatory, anticancer, anti-inflammatory, antinociceptive and as antipyretic. The study was carried out to ascertain analgesic and antipyretic activity of ethanolic extract of Solanum viarum Dunal leaves. The ethanolic extract of Solanum viarum Dunal leaves at 100 and $200 \mathrm{mg} / \mathrm{kg}$ oral single dose treatment show a significant difference $(\mathrm{p}<0.0001)$ in reaction time in terms of analgesic activity before and after treatments comparable to standard drug Diclofenac $(10 \mathrm{mg} / \mathrm{kg}$ body weight) and also reduced the elevated body temperature induced by Brewer's yeast. The extract also shows significant $(\mathrm{p}<0.0001)$ decrease in elevated body temperature at 100 and $200 \mathrm{mg} / \mathrm{kg}$ comparable to standard drug Paracetamol (150mg/kg body weight).

Keywords Solanum viarum Dunal, Analgesic activity, Antipyretic activity.

Article Info: Received 10 June 2018; Review Completed 14 July 2018; Accepted 16 July 2018; Available online 17 July 2018

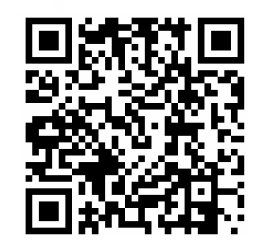

\section{Cite this article as:}

Kausar M, Singh BK, Pharmacological evaluation of Solanum viarum dunal leaves extract for analgesic and antipyretic activities, Journal of Drug Delivery and Therapeutics. 2018; 8(4):356-361 DOI: http://dx.doi.org/10.22270/jddt.v8i4.1812

Meena Kausar, Department of Pharmaceutical Sciences, Bhimtal, Kumaun University, Nainital-263136, India

\section{INTRODUCTION}

Injuries and diseases co-exist with pain and fever. The drugs that relief pain and lower the elevated body temperature are known as analgesic and antipyretic which comes under the category of non-steroidal antiinflammatory drugs or NSAIDS. These drugs prevent the synthesis of prostaglandins by inhibiting cyclooxygenase enzyme (COX) and relief pain and lower the elevated body temperature, but prostaglandins are also essential for synthesis of various components which causes GI mucosal defence. Hence NSAIDS are responsible for various gastrointestinal complications like perforation, obstructions, peptic ulcers, and bleeding. These complication are not occurs with selective COX-2 inhibitors but COX-2 inhibitors also cause cardiovascular and renal complications. Narcotic analgesics are the drugs used in the management of chronic pain but they possess various side effects like, sedation, addiction, tolerance, psychological dependency, constipation, respiratory depression and mainly social abuse. Furthermore, only $50 \%$ of existing analgesics contributing relief from pain in approx $30 \%$ of the patients, for minimize these adverse events, exploration for newer analgesic and antipyretic drugs is required. Natural products play important role in managing various type of diseases due to their medicinal properties. Approx $25 \%$ of synthetic compounds are directly or indirectly based on medicinal plants. Medicinal plants possess lower side effects, traditional uses and they are also found in abundance, they provide appropriate source for discovering the newer drugs to manage pain and fever.

Solanum viarum Dunal is commonly known as tropical soda apple belongs to family Solanaceae. It also has various synonyms like Solanum chloranthum, Solanum khasianum, Solanum viridifiorum etc. Solanum viarum 
described as a broad leaf herb, subshrub or shrub. In India, it is considered as a "woody herb", generally perennial, occurs in warm climate, remains green over the winter. They grow from 3-6 feet tall; leaves and stem are lined with thorn like prickles up to 1 inch $(2.5 \mathrm{~cm}$ long). The leaves are 2 to 8 inches $(6-20 \mathrm{~cm})$ long $x 2$ to 6 inches $(6-15 \mathrm{~cm})$ wide. Its inflorescence is a 1 to 3 flowered cyme. The fruits are globular berries, typically about 0.8 to 1 inch $(2-3 \mathrm{~cm})$ in diameter at maturity, but viable seed develop in ripe fruits as small as 0.4 inch $(1 \mathrm{~cm})$ in diameter. It contains chemical constituents like Soalsodine, Caffeoylquinic acid (CQA) derivatives, 5caffeoyl and 3-malonyl-5-caffeoyl-[4-(1 beta-[6-(5caffeoyl)quinate] glucopyranosyl)], quinic acid.

Solasodine is aglycone part of glycoalkaloids (nitrogen analogue of sapogenins). Solasodine having 27 carbon atoms (cholestane skeleton) and it can be converted into dihydropregnenolone. Dihydropregnenolone is a important intermediate in synthesis of many steroidal drugs like progesterone and cortisone. ${ }^{1}$

\section{MATERIAL AND METHODS}

Diclofenac, Paracetamol and Brewer's yeast, were purchased from Yarrow Chem Products Mumbai, and other chemicals were used of laboratory grade.

\section{Collection and Identification of Plant}

The Solanum viarum Dunal leaves were collected from Naukuchiatal road site of Bhimtal region District Nainital. The specimen was identified and authenticated by Botanical Survey of India (BSI) NRC Dehradun.
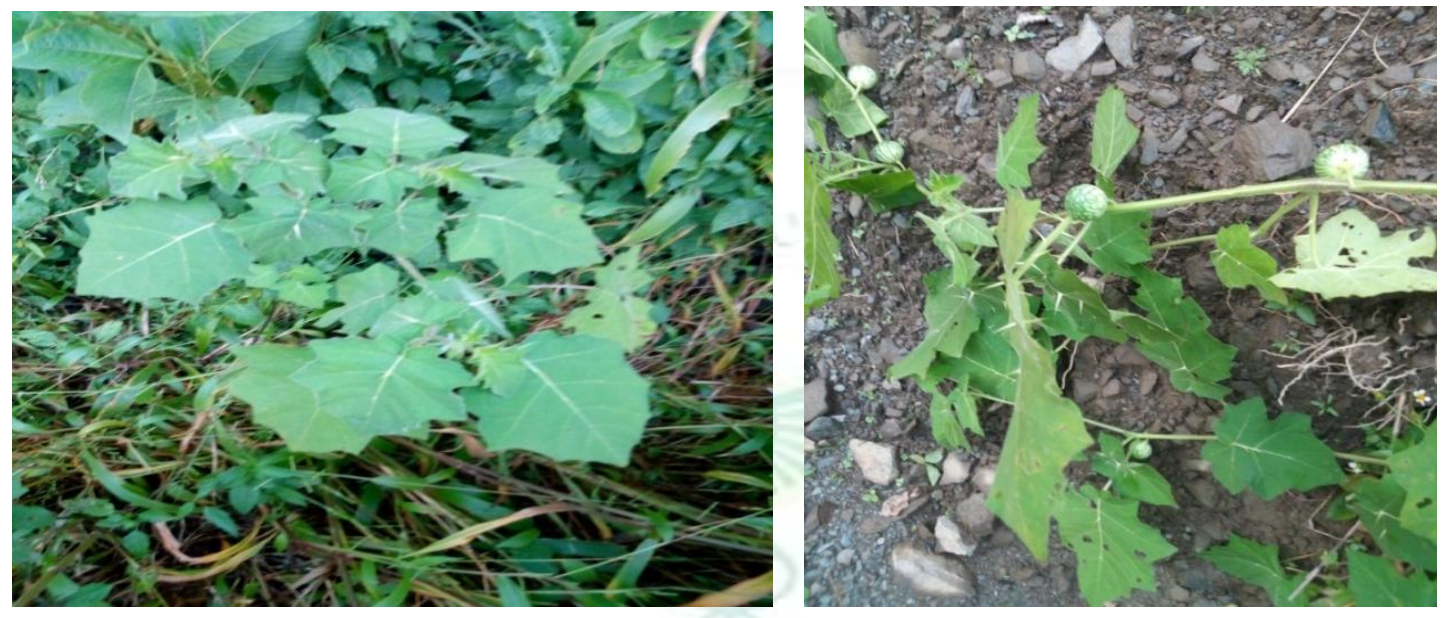

Figure 1: Solanum viarum Dunal

\section{Preparation of extract of Solanum viarum Dunal}

Shade dried leaves of Solanum viarum Dunal were grounded to fine powder in an electric grinder and sieved. $150 \mathrm{gm}$ of dried powder were extracted with $1500 \mathrm{ml}$ of ethanol. It was subjected to reflux for 2 cycles, which was further evaporated to dryness to obtain ethanolic extract. The percentage yield of extract was $30.19 \% \mathrm{w} / \mathrm{w}$ with respect to the original air dried powder was obtained. ${ }^{12}$ The extract was finally stored in air tight container, in dry place for further use in experiment.

\section{Experimental Animals}

Healthy Wistar rats (200-250gm) of either sex were used for this study. They were acclimated to laboratory environment for 7 days before the beginning of the experiment, with alternative light-dark cycle of $12 \mathrm{hrs}$ and were allowed free access to standard dry pellet diet and water ad libitum. Animals were fasted overnight with free access to water preceding the experiment. The study was performed according to the Committee for the Purpose of Control and Supervision of Experiments on Animals (CPCSEA) guidelines. ${ }^{2,3}$

\section{Preliminary Phytochemical Tests}

The ethanolic extract of Solanum viarun Dunal leaves were tested for different phytoconstituents like alkaloids, saponin, flavanoids, proteins, phenolic compounds, tannins, terpenoids and steroids. ${ }^{4,5}$

\section{Acute Oral Toxicity Studies}

Acute oral toxicity study was carried out for ethanolic extract of Solanum viarum Dunal leaves using Acute Toxic class method as described in OECD (Organization of Economic Co-Operation and Development) guidelines no. 423 on female Wistar rats.

\section{Analgesic activity}

\section{Hot Plate Method}

The paws of mice and rats are particularly responsive to heat at a temperature which not damaging the skin. The responses include withdrawal of the paws, jumping and licking of the paws. The Wistar rats (either sex) weighing between 200-250gm were divided into four groups each group having six animals. The animals were weighed and numbered appropriately. The group first considered as control group and received only distilled water and second group considered as standard group and received Diclofenac sodium $10 \mathrm{mg} / \mathrm{kg}$. Third and fourth groups received Solanum viarum Dunal leaf extract $\left(\mathrm{T}_{1} 200 \mathrm{mg} / \mathrm{kg}\right.$ and $\mathrm{T}_{2} 400 \mathrm{mg} / \mathrm{kg}$ ) respectively and the animals were positioned on the hot plate and the time until either licking or jumping occurs is note down by a stop-watch for $0,30,60,120$ and 180 minutes. Fifteen 
second cut off time was taken to avoid the damage of paw $\operatorname{skin}^{6}$

\section{Tail flick method}

The application of thermal radiation to the tail of an animal provokes the tail withdrawal. The withdrawal of tail from the heat source, referred to as "tail flick latancy".

Wistar rats having weight between 200-250gm were placed into four groups and each group having six animals. The first group was considered as control group and received distilled water and second one considered as standard group and received Diclofenac sodium $10 \mathrm{mg} / \mathrm{kg}$. Third and fourth groups received Solanum viarum Dunal leaf extract $\left(\mathrm{T}_{1} 200 \mathrm{mg} / \mathrm{kg}\right.$ and $\mathrm{T}_{2}$ $400 \mathrm{mg} / \mathrm{kg}$ ) respectively. The rat tail was located on analgesiometer that was previously maintained at $55^{\circ} \mathrm{c}$ and nociceotive response latency of time flicking of tail was recorded $0,30,60,120$ and 180 minutes. Usually withdrawal time is about $2-10 \mathrm{sec}$ and the cut off time is 10 sec. $^{7}$

\section{Antipyretic activity}

\section{Brewer's yeast induced pyrexia in rats}

Antipyretic activity on Wistar rats was performed with Brewer's yeast induced pyrexia. The rats (weight 200$250 \mathrm{gm}$ ) were divided into four groups each containing six animals. Firstly basal rectal temperature was taken by inserting $1-2 \mathrm{~cm}$ of digital thermometer in rat rectum. After taking the basal rectal temperature, intraperitoneally $15 \%$ of Brewer's yeast injection in normal saline was injected to induce pain at a dose of $10 \mathrm{ml} / \mathrm{kg}$ of body weight. Later than $18 \mathrm{hrs}$ of injection, rats which showed a rise in temperature of at least $1^{0} \mathrm{c}$ were taken for the study. Animals were treated with test and standard drugs after $18 \mathrm{hrs}$ of yeast injection and temperature of rat's rectum was measured for 1,2, 3 and 4 hrs after treatment. ${ }^{8}$

We can represent percentage reduction in rectal temperature as;

$$
=\frac{\mathrm{Y}-\mathrm{X}}{\mathrm{Y}-\mathrm{Z}} \mathrm{X} 100
$$

Where,

$\mathrm{Z}$ represents initial rectal temperature $\left(\right.$ in $\left.^{0} \mathrm{c}\right)$.

$\mathrm{Y}$ represents rectal temperature after $18 \mathrm{hrs}$ of administration of yeast (in ${ }^{0} \mathrm{c}$ ).

$\mathrm{X}$ represents rectal temperature after administration of extract (in $\left.{ }^{0} \mathrm{c}\right)$.

\section{RESULT}

Hot plate test- The result of analgesic activity of the ethanolic extract of the leaves of Solanum viarum Dunal by Hot plate method are shown in Table 1 and graphically presented as Fig 1 . The rats of control group (treated with normal saline) did not show any difference in reaction time during conduction of hot plate test. The rats treated with standard drug Diclofenac were showed significant $(\mathrm{p}<0.0001)$ increase in reaction time and the rats treated with ethanolic extract of Solanum viarum Dunal leaves were also showed significant $(\mathrm{p}<0.0001)$ increase in reaction time. The highest reaction time for the higher concentration extract treated $\left(\mathrm{T}_{2} 200 \mathrm{mg} / \mathrm{kg}\right)$ group was 8.0 second at 180 minutes while it was 7.8 second at 180 minutes for lower concentration extract treated $\left(\mathrm{T}_{1} 100 \mathrm{mg} / \mathrm{kg}\right)$ group and for standard drug treated group it was 8.1 second at 180 minutes. Both the extracts were found to cause time-dependently prolongation of hot plate latency. The longest latency was obtained at 180 minutes post administration of the extract or the reference drug. The standard drug diclofenac $(10 \mathrm{mg} / \mathrm{kg})$ was more potent than the extracts at all time levels at $200 \mathrm{mg} / \mathrm{kg}$. The leaves extract showed significant result at 60,90,120 and $180 \mathrm{~min}$ in compare to control. No significant difference was observed between the extract and diclofenac treated groups.

Fig 1 shows diclofenac elicit significant analgesic activity within 30 minutes after administration and analgesic activity gradually increased with time. Similarly, the extract also shows significant analgesic activity within 30 minutes and activity also gradually increases with time.

Tail Flick test- The result of analgesic activity of the ethanolic extract of the leaves of Solanum viarum Dunal by Tail Flick method are shown in Table 2 and graphically presented as Fig 2. Rats of control group did not show any significant difference in tail flick latancy throughout the reaction time. The rats of standard group (treated with diclofenac) were showed a significant $(\mathrm{p}<0.0001)$ difference in reaction time between before and after administration of diclofenac. The maximum tail flick latancy observed was 7.1 second at 180 minutes with higher concentration of extract $\left(\mathrm{T}_{2} 200 \mathrm{mg} / \mathrm{kg}\right)$ while for standard drug the tail flick latancy was 7.0 second at 180 minutes. The tail flick latency for $\mathrm{T}_{1}$ $(100 \mathrm{mg} / \mathrm{kg})$ was 6.8 second at 180 minutes. The $\mathrm{T}_{2}$ show 0.1 second of increment in reaction time in comparison to standard drug.

Fig 2 The $T_{1}$ and $T_{2}$ show significant analgesic activity within $30 \mathrm{~min}$ of administration and gradually increase with time.

Brewer's yeast induced pyrexia test- The result of antipyretic activity of the ethanolic extract of the leaves of Solanum viarum Dunal by Brewer's yeast induced pyrexia test are shown in Table 3 and graphically presented as Fig 3. The control group showed elevation in body temperature after administration of Brewer's yeast. The rats of extract treated group $\left(\mathrm{T}_{2} 200 \mathrm{mg} / \mathrm{kg}\right)$ showed $38^{\circ} \mathrm{c}$ elevation in body temperature after $18 \mathrm{hrs}$ of Brewer's yeast injection which was become $35^{\circ} \mathrm{c}$ after $4 \mathrm{hrs}$ of $\mathrm{T}_{2}$ administration.

Fig. 3 illustrate Standard drug paracetamol $150 \mathrm{mg} / \mathrm{kg}$ and both the test drugs orally showed significant $(\mathrm{P}<0.0001)$ difference in body temperature in $1,2,3$, and $4 \mathrm{hr}$ of time interval respectively. 


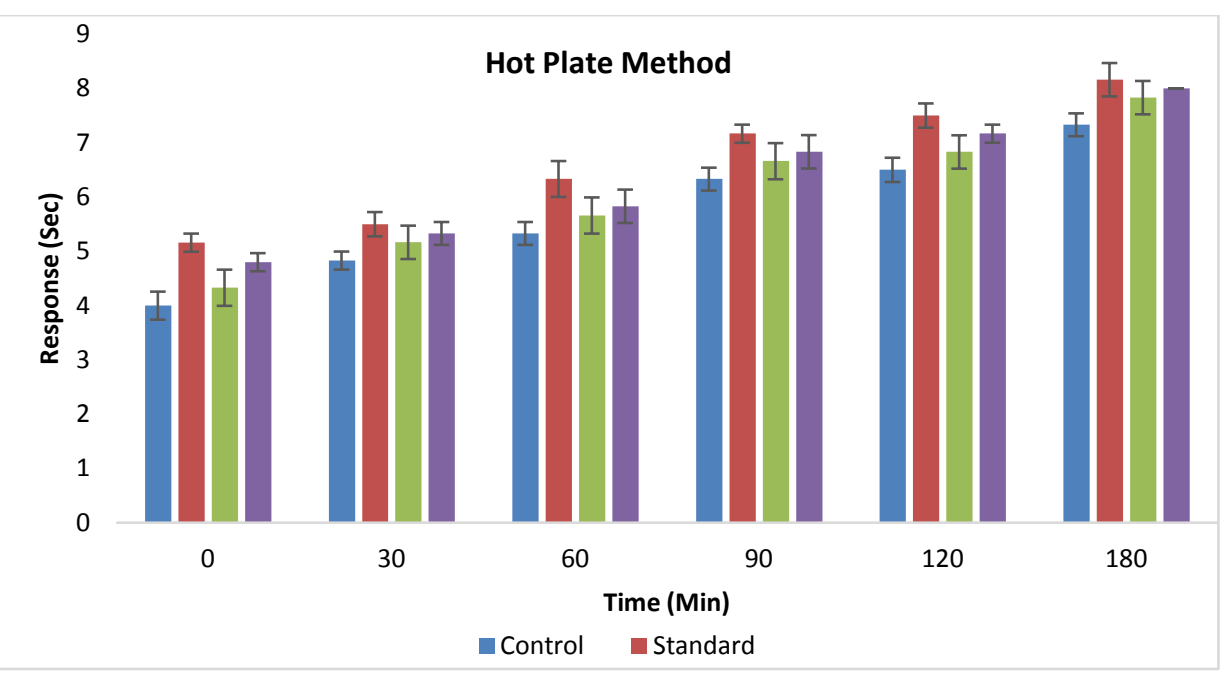

Figure 2: Analgesic Activity by Hot Plate Method [standard- Diclofenac $(10 \mathrm{mg} / \mathrm{kg}), \mathrm{T}_{1^{-}}$Solanum viarum Dunal Ethanolic Extract(100mg/kg), $\mathrm{T}_{2}$-Solanum viarum Dunal Ethanolic Extract $\left.(200 \mathrm{mg} / \mathrm{kg})\right]$

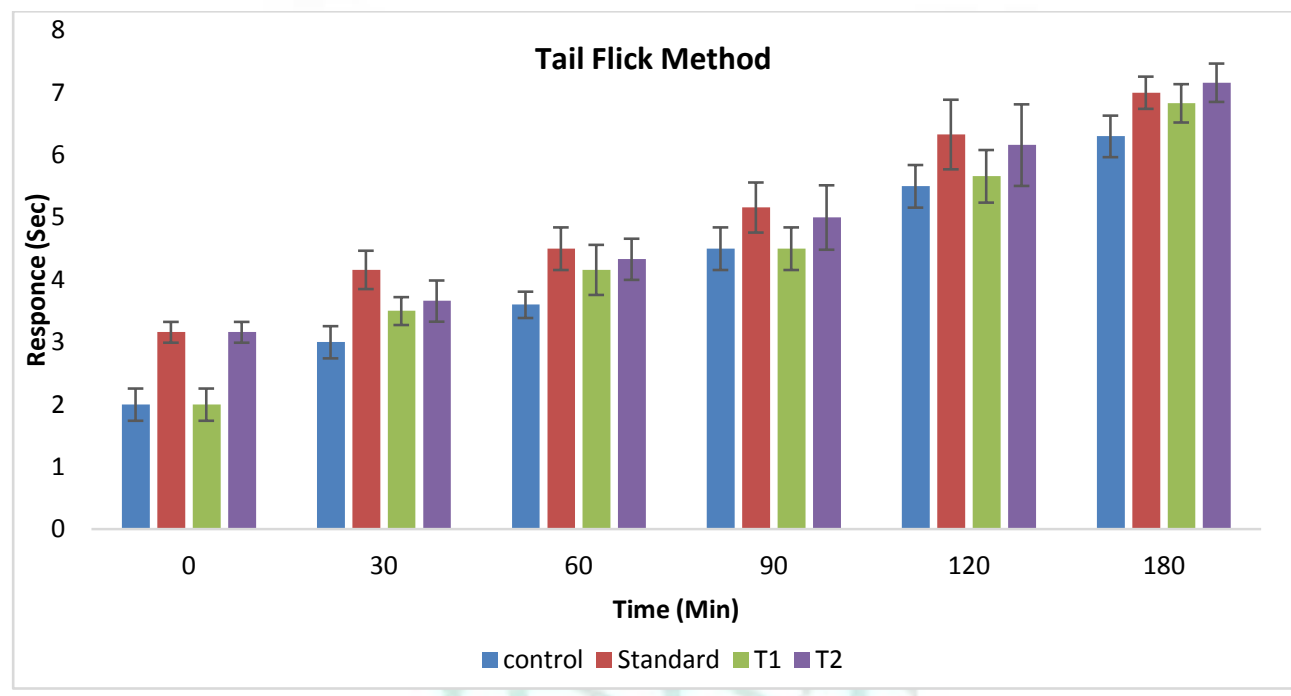

Figure 3: Analgesic Activity by Tail Flick Method in Rats [standard- Diclofenac (10mg/kg), $\mathrm{T}_{1}$-Solanum viarum Dunal Ethanolic Extract (100mg/kg) $\mathrm{T}_{2}$-Solanum viarum Dunal Ethanolic Extract $\left.(200 \mathrm{mg} / \mathrm{kg})\right]$

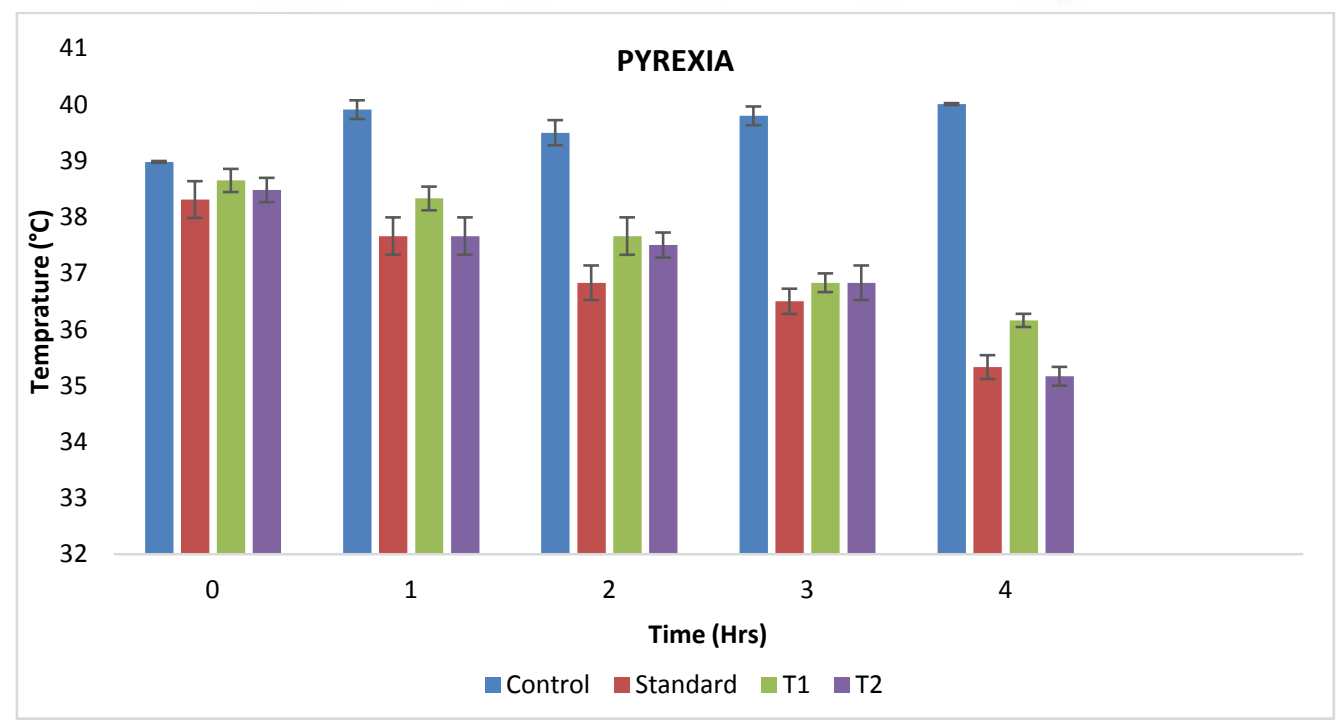

Figure 4: Antipyretic Activity by Brewer's Yeast Induced Pyrexia Method in Rats [standard- Paracetamol (150mg/kg), $\mathrm{T}_{1}$ - Solanum viarum Dunal Ethanolic Extract(100mg/kg), $\mathrm{T}_{2}$ - Solanum viarum Dunal Ethanolic Extract $\left.(200 \mathrm{mg} / \mathrm{kg})\right]$ 


\section{Effect on analgesia}

\section{Analgesic effect by hot plate method}

Table 1: Values are expressed as mean \pm SEM $(\mathrm{N}=6)$, standard $\mathrm{p}<0.0001$ significant with respect to the control, and in test $2 \mathrm{p}<0.0001$ significant with respect to the control group by one way ANOVA test.

\begin{tabular}{|c|c|c|c|c|c|c|c|}
\hline \multirow{2}{*}{ Groups } & \multirow{2}{*}{ Dose } & \multicolumn{7}{|c|}{ Reaction time in sec } \\
\cline { 3 - 8 } & & $\begin{array}{c}\mathbf{0} \\
\text { min }\end{array}$ & $\begin{array}{c}\mathbf{3 0} \\
\text { Min }\end{array}$ & $\begin{array}{c}\mathbf{6 0} \\
\text { min }\end{array}$ & $\begin{array}{c}\mathbf{9 0} \\
\text { min }\end{array}$ & $\begin{array}{c}\mathbf{1 2 0} \\
\text { Min }\end{array}$ & $\mathbf{1 8 0}$ min \\
\hline Control & $10 \mathrm{ml} / \mathrm{kg}$ & $4 \pm 0.2582$ & $4.83 \pm 0.166$ & $5.33 \pm 0.2108$ & $6.33 \pm 0.2108$ & $6.5 \pm 0.2236$ & $7.33 \pm 0.2106$ \\
\hline $\begin{array}{c}\text { Standard } \\
\text { Diclofenac sod }\end{array}$ & $10 \mathrm{mg} / \mathrm{kg}$ & $5.16 \pm 0.166$ & $5.5 \pm 0.2236$ & $6.33 \pm 0.2108$ & $7.16 \pm 0.2108$ & $7.5 \pm 0.2236$ & $8.16 \pm 0.3073$ \\
\hline Test drug $\left(\mathrm{T}_{1}\right)$ & $200 \mathrm{mg} / \mathrm{kg}$ & $4.33 \pm 0.333$ & $5.16 \pm 0.307$ & $5.66 \pm 0.333$ & $6.66 \pm 0.333$ & $6.83 \pm 0.307$ & $7.83 \pm 0.3073$ \\
\hline Test drug $\left(\mathrm{T}_{2}\right)$ & $400 \mathrm{mg} / \mathrm{kg}$ & $4.8 \pm 0.1667$ & $5.33 \pm 0.210$ & $5.83 \pm 0.3073$ & $6.83 \pm 0.3073$ & $7.16 \pm 0.166$ & 8 \\
\hline
\end{tabular}

\section{Analgesic effect by tail flick method}

Table 2: Values are expressed as mean \pm SEM $(N=6)$, standard $p<0.0001$ significant with respect to the control, by one way ANOVA test.

\begin{tabular}{|c|c|l|l|l|l|l|l|}
\hline \multirow{2}{*}{ Groups } & \multirow{2}{*}{ Dose } & \multicolumn{1}{|c|}{ Reaction time in sec } \\
\cline { 3 - 8 } & $10 \mathrm{ml} / \mathrm{kg}$ & $2 \pm 0.2582$ & $3 \pm 0.2582$ & $3.6 \pm 0.2108$ & $4.5 \pm 0.341$ & $5.5 \pm 0.341$ & $6.3 \pm 0.333$ \\
\hline Control & $10 \mathrm{mg} / \mathrm{kg}$ & $3.16 \pm 0.166$ & $4.16 \pm 0.307$ & $4.5 \pm 0.3416$ & $5.16 \pm 0.401$ & $6.33 \pm 0.557$ & $7 \pm 0.258$ \\
\hline $\begin{array}{c}\text { Standard } \\
\text { Diclofenac sod. }\end{array}$ & & & & & & & \\
\hline Test drug $\left(\mathrm{T}_{1}\right)$ & $200 \mathrm{mg} / \mathrm{kg}$ & $2 \pm 0.2582$ & $3.5 \pm 0.223$ & $4.16 \pm 0.4014$ & $4.5 \pm 0.3416$ & $5.66 \pm 0.421$ & $6.83 \pm 0.307$ \\
\hline Test drug $\left(\mathrm{T}_{2}\right)$ & $400 \mathrm{mg} / \mathrm{kg}$ & $3.16 \pm 0.166$ & $3.66 \pm 0.33$ & $4.33 \pm 0.33$ & $5 \pm 0.5164$ & $6.16 \pm 0.654$ & $7.16 \pm 0.307$ \\
\hline
\end{tabular}

\section{Effect on pyrexia}

\section{Antipyretic effect by brewer's yeast induced pyrexia}

Table 3: Values are expressed as mean \pm SEM $(\mathrm{N}=6)$, standard $\mathrm{p}<0.0001$ significant with respect to the control, by one way ANOVA test.

\begin{tabular}{|c|c|l|l|l|l|c|}
\hline \multirow{2}{*}{ Groups } & \multirow{2}{*}{ Dose } & \multicolumn{5}{|c|}{ Reaction time in hrs } \\
\cline { 3 - 7 } & $10 \mathrm{ml} / \mathrm{kg}$ & $38.98 \pm 0.01667$ & $39.91 \pm 0.166$ & $39.5 \pm 0.2236$ & $39.8 \pm 0.1667$ & $40.01 \pm 0.016$ \\
\hline Control & $150 \mathrm{mg} / \mathrm{kg}$ & $38.31 \pm 0.327$ & $37.66 \pm 0.333$ & $36.83 \pm 0.307$ & $36.5 \pm 0.2236$ & $35.33 \pm 0.212$ \\
\hline Standard Paracetamol & $200 \mathrm{mg} / \mathrm{kg}$ & $38.65 \pm 0.2062$ & $38.33 \pm 0.210$ & $37.66 \pm 0.333$ & $36.83 \pm 0.166$ & $36.16 \pm 0.117$ \\
\hline Test drug $\left(\mathrm{T}_{1}\right)$ & $400 \mathrm{mg} / \mathrm{kg}$ & $38.48 \pm 0.2167$ & $37.66 \pm 0.333$ & $37.5 \pm 0.2236$ & $36.83 \pm 0.307$ & $35.16 \pm 0.166$ \\
\hline Test drug $\left(\mathrm{T}_{2}\right)$ & &
\end{tabular}

\section{DISCUSSION}

Currently available drug regimens for management of analgesic, antipyretic and anti-inflammatory activity have certain drawbacks and therefore there is a need for safer and more effective drugs. The use of traditional medicine and medicinal plants in most developing countries, as a normative basis for the maintenance of good health has been widely observed.

The study indicated that Solanum viarum Dunal leaves extract has analgesic and antipyretic activities. The analgesic activity was studied by using thermal test (hot plate and tail flick method). The thermal tests were selected to evaluate analgesic activity of the extract because temperature induces pain and this pain can be utilized to study the analgesic efficacy of the extract. The tail of the animal are very sensitive to heat or thermal stimuli, tail flick method was used for the evaluation of analgesic activity of drug. In hot plate method, a plate was heated on constant temperature produces two behavioural responses (that can be measured in terms of their reaction times), namely paw licking and jumping. Both are considered to be supraspinally integrated responses. ${ }^{9}$ The extract produced a prolongation of time latency in all the tests. ${ }^{10}$ It is well known that most analgesic drugs possess antipyretic activity. The antipyretic activity of the extract was determined by yeast induce pyrexia method. In the present study, rise of temperature after $18 \mathrm{hrs}$ of subcutaneous yeast injection was above $38^{\circ} \mathrm{c}$. There was a significant difference between the initial mean basal temperature of the different groups and the mean temperature of pyrexia rats. Rectal temperature of pyrexia rats were lowered significantly with the test drug and standard drug. Standard drug paracetamol is more potent than the test extract ${ }^{11}$ No toxicity was seen in the test drug treated groups after $24 \mathrm{hrs}$ of experiment. So the test drug is a safer antipyretic agent. 


\section{CONCLUSION}

Based on the result of this study, it was concluded that leaf extract of Solanum viarum Dunal have analgesic and antipyretic activities when used orally at a dose of 100 and 200mg/kg. Phytochemical analysis has been done. The data collectively indicate the leaf extract of Solanum viarum Dunal possesses analgesic and

\section{REFERENCES}

1. Kanika patel, Ravi B. singh, Dinesh K. patel., Medical significance, Pharmacological activities and analytical aspects of Solasodine: A concise report of current scientific literature. Journal of Acute Disease 2013; 2:92-98.

2. Shaik HA, Eswaraih MC, Lahari M, Rao BM, Ali S, Evaluation of analgesic and antipyretic activities of ethanolic extract of Terminalia pallida stem in experimental animals, Scholars Journal of AppliedMedicalSciences (SJAMS), 2013; 1(1):5-8

3. Patel A, Patel T, Carol Macwan, Mayuree Patel, Khushbuchauhan, Jatin Patel, Evaluation of Antiinflammatory and Analgesic activity of roots of Rubiacordifolia in rats. Journal of Pharmaceutical Science and Research 2010; 2(12):809-813.

4. Gogoi P, Islam M, Phytochemical Screening of Solanumnigrum L. \& S. myriacanthus. IOSR Journal of Pharmacy 2012; 2(3): 455-459.

5. Shree Devi MS, V. Ravichandrian and S. Jaya Kumari, Phytochemical study on SolanumxanthocarpumChooranum. International Journal of Frontiers in Science and Technology (IJFST) IISN 2321-0494. antipyretic activities which is probably mediated by both central and peripheral inhibitory mechanism as well as via inhibition of prostaglandins synthesis. In conclusion, this study demonstrated that the leaf of Solanum viarum Dunal has marked analgesic and antipyretic activities. The present study offered of scientific evidence to the traditional use of Solanum viarum Dunal as analgesic, antipyretic agent.

6. Mishra D, Ghosh G, P. Sudhir Kumar and Prasannakumar panda, An Experimental study of Analgesic activity of selective cox-2 inhibitors with conventional NSAIDs. Asian Journal of Pharmaceutical and clinical research 2011; 4(1):58.

7. Parel M, Yadav M, Laboratory models for screening Analgesics. International Research Journal of pharmacy 2013; 4(1):15-19.

8. Sunelkumar A, Venkatarathanamma V, NAGA Saibabu V, Seetha Ram K, Antipyretic activity of Annova plants leaves on Brewer's yeast induced febrile rats. Asian Journal of Pharmaceutical and clinical research 2015; 3(8):210-212.

9. Milind P, Monu Y. Laboratory models for scavenging analgesic. I nternational Research Journal of Pharmacy 2013; 4:15-19.

10. Dafny N. Pain principles department anatomy. 2010; 5:267269.

11. Jain BB, Rathi BS, Thakurdesai PA and Bodhankar SL. Antipyretic activity of aqueous extract of leaves of Cocculus hirsule. Indian J Nat Prod. 2007; 23:26-29.

12. Dr. C. K. Kokate, Extraction of cude soladine from berries of Solanum khasianum, Practical Pharmacognosy 2014; 5:169. 